\title{
ANALISA KERUNTUHAN BENDUNGAN TUGU KABUPATEN TRENGGALEK
}

\author{
Pradoko Indra Purwanto $^{1}$, Pitojo Tri Juwono ${ }^{2}$, Runi Asmaranto ${ }^{2}$ \\ ${ }^{1}$ Pengawas Pengairan Dinas Pekerjaan Umum Pengairan Kabupaten Magetan, \\ ${ }^{2}$ Dosen Fakultas Teknik Jurusan Pengairan. \\ E-mail: pradoko86@yahoo.com.
}

\begin{abstract}
ABSTRAK: Bendungan Tugu yang termasuk dalam sistem pengaliran sungai Keser dan berlokasi di Kabupaten Trenggalek, Propinsi Jawa Timur telah disimulasikan runtuh dengan menggunakan perangkat lunak HEC-RAS 5.0.1. Sebaran banjir yang terjadi akibat keruntuhan Bendungan Tugu dengan skenario overtopping memiliki dampak yang lebih besar daripada skenario akibat piping atas. Pada skenario piping atas karakteristik banjir di lokasi terpilih yang paling parah adalah Desa Nglinggis pada jarak 500 meter dengan kedalaman banjir 7.26 meter, kecepatan aliran banjir 12.44 meter/detik, dan waktu tiba banjir 40 detik sedangkan pada skenario overtopping karakteristik banjir di lokasi terpilih yang paling parah adalah Desa Nglinggis pada jarak 500 meter dengan kedalaman banjir 7.94 meter, kecepatan aliran banjir 12.44 meter/detik, dan waktu tiba banjir 40 detik. Sehingga dalam analisa sebaran banjir digunakan skenario keruntuhan bendungan akibat overtopping yang secara administratif mencakup 14 Desa, 4 Kecamatan di Wilayah Kabupaten Trenggalek dengan jumlah penduduk yang terkena resiko diperkirakan mencapai 59.925 jiwa. Berdasarkan SK Dirjen SDA PU, tahun 2011 Bendungan Tugu diklasifikasikan Bahaya Sangat Tinggi.

Keruntuhan bendungan mempunyai dampak yang sangat besar, sehingga diperlukan upaya pencegahan keruntuhan bendungan. Dari hasil analisa, Bendungan Tugu mempunyai potensi overtopping sehingga dapat memicu keruntuhan bendungan. Rekomendasi pencegahan dengan cara teknis yaitu dengan membuat emergency spillway sebesar 6 meter atau meninggikan tubuh bendungan sebesar 1 meter. Sedangkan keruntuhan bendungan akibat piping dapat dicegah dengan cara menurunkan muka air waduk dibawah elevasi kerusakan bendungan.
\end{abstract}

Kata kunci: Keruntuhan, Bendungan Tugu, Hec-Ras, Overtopping

ABSTRACT: Tugu Dam is located on the watershed system of Kali Keser in Trenggalek, East Java province. Tugu Dam has been simulated collapsed by dam break simulation with HEC-RAS 5.0.1 software. The spreading of floods caused by the collapsed of Tugu Dam with the overtopping scenario has a greater impact than the upper piping effect scenario. The worst affected of The upper piping scenario of flood characteristics on the selected location, is Nglinggis Village with distance 500 meters and depth 7.26 meters, velocity is $12.44 \mathrm{~m} / \mathrm{s}$, and flood time arrived 40 second. So, this research analyze dam break simulation based on overtopping that has been covered 14 Villages, 4 sub-districts in Trenggalek district with affected people estimated 59,925 people. Based on SK Dirjen SDA PU 2011, the risk type of Tugu Dam was classified into High Risk Dam

Dam break has biggest impact, therefore needed effort to prevent it. The result of this analysis, Tugu Dam, that has a overtopping potential can trigger the dam collapse. Prevention technical recommendation is to make emergency spillway 6 meters or increase crest dam 1 meter, while dam break caused by piping can be prevented by lowering the water level of the reservoir below the elevation of risk dam.

Keywords: Dam Break, Tugu Dam, Hec-Ras, Overtopping

Bencana adalah suatu peristiwa atau rangkaian peristiwa yang mengancam dan mengganggu kehidupan dan penghidupan masyarakat yang disebabkan baik oleh faktor alam dan atau 
faktor non alam maupun faktor manusia, sehingga mengakibatkan timbulnya korban jiwa manusia, kerusakan lingkungan, kerugian harta benda dan dampak psikologis yang sering berkepanjangan. Bendungan, disamping bermanfaat untuk memenuhi berbagai kebutuhan bagi manusia, juga menyimpan potensi bahaya yang sangat besar. Bendungan Tugu adalah bendungan dengan tipe Urugan Batuan Random dengan inti tegak zonal. Bendungan pengelak nantinya akan dimanfaatkan menjadi satu kesatuan dengan tubuh bendungan utama. Bendungan utama direncanakan mampu menahan debit banjir dengan periode ulang 1000 tahun $\left(\mathrm{Q}_{1000}\right)$ sebesar $670,95 \mathrm{~m}^{3} /$ detik dengan dikontrol debit $\mathrm{Q}_{\mathrm{PMF}}$ sebesar 928,44 $\mathrm{m}^{3} /$ detik. Dari beberapa kasus keruntuhan / kegagalan bendungan, bendungan tipe urugan ini adalah paling sering terjadi kerusakan bendungan. Berikut di bawah ini adalah beberapa contoh kasus keruntuhan bendungan yang terjadi di dunia (tabel 1).

Pada penelitian kali ini akan dilakukan simulasi keruntuhan Bendungan Tugu dengan bantuan perangkat lunak Hec-Ras 5.0.1. Lokasi Bendungan Tugu Kabupaten Trenggalek ini berada di Desa Nglinggis Kecamatan Tugu Kabupaten Trenggalek Propinsi Jawa Timur.Secara geografis terletak pada kooordinat $08^{\circ} 02^{\prime} 27^{\prime \prime}$ LS dan $111^{\circ} 35^{\prime} 07^{\prime \prime}$ BT , lokasi terletak di pinggir kiri jalan raya kabupaten yang menghu-bungkan kota Trenggalek - Ponorogo, pada $\mathrm{km} \pm 15.00$ dari kota Trenggalek ke arah barat kemudian berbelok ke kiri $+1 \mathrm{~km}$ memasuki jalan desa yang dapat ditempuh dengan kendaraan roda empat.

Dalam penelitian ini akan dibahas beberapa permasalahan mengenai Analisa Keruntuhan Bendungan Tugu, yang meliputi:

1. Bagaimana karakteristik kedalaman banjir dan kecepatan banjir akibat keruntuhan bendungan di Bendungan Tugu?

2. Bagaimana batas genangan banjir dan waktu tiba banjir yang dihasilkan akibat keruntuhan Bendungan Tugu?

3. Bagaimana rekomendasi untuk mencegah keruntuhan Bendungan Tugu?

Analisis penelusuran banjir ini, bermanfaat untuk dapat mengetahui parameterparameter penyebab runtuhnya bendungan, profil muka air banjir maksimum serta hidrograf banjir pada daerahhilir bendungan di wilayah studi, berupa peta genangan banjir. Peta genangan yang didapatkan kemudian digunakan sebagai langkah awal mitigasi dalam rangka pembuatan peta resiko rawan banjir akibat keruntuhan bendungan.

Tabel 1. Beberapa Contoh Kerusakan Bendungan di Dunia

\begin{tabular}{|c|c|c|c|c|}
\hline Dam/Reservoir & Location & Year & Main Reason & Death toll/Cost \\
\hline Gintung & Indonesia & 2010 & Overtopping & 99 people \\
\hline Taum Sauk & USA & 2005 & Overtopping & $\begin{array}{l}\text { Damage } \\
\text { avoided }\end{array}$ \\
\hline Big Bay Dam & USA & 2004 & $\mathrm{~N} / \mathrm{A}$ & $\begin{array}{l}100 \text { homes } \\
\text { destroyed }\end{array}$ \\
\hline Folsom Dam & USA & 1995 & Spillway & $\begin{array}{l}\text { Damage } \\
\text { avoided }\end{array}$ \\
\hline $\begin{array}{l}\text { Val di Stava } \\
\text { Dam }\end{array}$ & Italy & 1985 & $\begin{array}{l}\text { Improper } \\
\text { maintenance/Desi } \\
\text { gn }\end{array}$ & $\begin{array}{l}268 \text { people, } 155 \\
\text { euro million inda } \\
\text { damage }\end{array}$ \\
\hline Tous Dam & Spain & 1982 & $\begin{array}{l}\text { Insuffisient } \\
\text { spillway }\end{array}$ & 20 people \\
\hline $\begin{array}{l}\text { Morvi River } \\
\text { Dam }\end{array}$ & India & 1979 & Overtopping & 15.000 people \\
\hline $\begin{array}{l}\text { Laurel Run } \\
\text { Dam }\end{array}$ & USA & 1977 & Overtopping & $\begin{array}{l}40 \text { people } / \$ 5.3 \\
\text { million }\end{array}$ \\
\hline $\begin{array}{l}\text { Kelly Barnes } \\
\text { Dam }\end{array}$ & USA & 1977 & Piping & $\begin{array}{l}39 \text { people/\$2.5 } \\
\text { million }\end{array}$ \\
\hline Teton Dam & USA & 1976 & Foundation & $\begin{array}{l}14 \text { people } / \$ 1 \\
\text { billion in } \\
\text { property } \\
\text { damage }\end{array}$ \\
\hline Banqiao Dam & China & 1975 & Overtopping & 200.000 people \\
\hline Baldwin Hills & USA & 1963 & $\begin{array}{l}\text { Ground } \\
\text { movement from oil } \\
\text { extraction }\end{array}$ & 5 people \\
\hline $\begin{array}{l}\text { Maupassant } \\
\text { Dam }\end{array}$ & France & 1959 & $\begin{array}{l}\text { Overtopping/found } \\
\text { ation }\end{array}$ & 450 people \\
\hline $\begin{array}{l}\text { St. Francis } \\
\text { Dam }\end{array}$ & USA & 1928 & Foundation & 450 people \\
\hline Austin Dam & USA & 1911 & Foundation & 87 people \\
\hline
\end{tabular}

Sumber: Konstruksi Bendungan Urugan Vol.1 (Masrevaniah, 2010)

\section{BAHAN DAN METODE}

\section{a. Bahan}

Analisa ini menggunakan beberapa data antara lain:

- Peta RBI skala 1:25.000 dan Peta DEM

- Data sistem pengaliran bendungan

- Peta Daerah Tangkapan Air (DTA)

- Data teknis Bendungan Tugu

- Lengkung kapasitas waduk

- Data curah hujan harian \pm 20 tahun

- Peta Isohyet Indonesia yang dikeluarkan Dirjen SDA Kementerian Pekerjaan Umum tahun 2011

\section{b. Metode}

Sebelum bendungan mengalami keruntuhan total, didahului oleh terjadinya rekahan (breaching). Rekahan adalah lubang 
yang terbentuk dalam tubuh bendungan pada saat runtuh. Skenario keruntuhan yang digunakan pada penelitian ini ditinjau 2 kondisi yaitu Overtoping maupun Piping.

Rekahan karena overtopping disimulasikan berupa rekahan yang berbentuk segi empat, segitiga atau trapesium. Rekahan tersebut makin lama makin membesar dengan waktu secara progresif dari puncak bendungan ke bawah sampai mencapai pondasi. Aliran yang melewati rekahan diperhitungkan sebagai aliran melewati ambang lebar

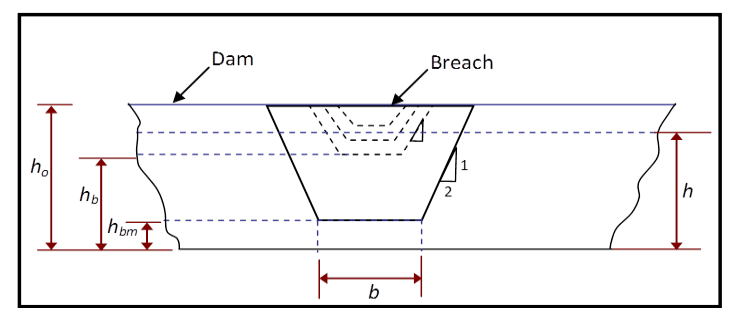

Gambar 1. Tampak depan dari formasi perubahan ukuran rekahan yang terjadi pada tubuh dam akibat overtopping

Keruntuhan bendungan akibat piping dapat disimulasikan dengan menentukan elevasi sumbu dari piping bendungan. Ini disimulasikan sebagai rekahan lubang (orifice) berbentuk segipanjang.

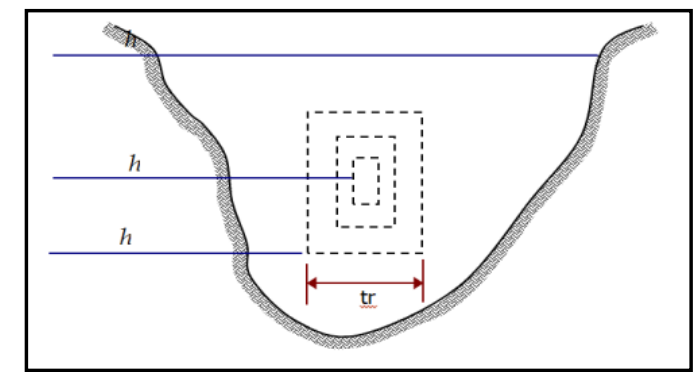

Gambar 2. Tampak depan dari formasi perubahan ukuran rekahan yang terjadi pada tubuh dam akibat Piping

Debit yang keluar dari kedua macam rekahan tersebut merupakan hidrograf banjir yang terjadi pada penampang melintang 0 (permulaan), yang harus ditelusur ke hilir di sepanjang lembah sungai dengan metode "Unsteady flow" (Hidrolika Saluran Terbuka (Open Channel Hydraulics). Ven Te Chow, 1985).

Model Matematis persamaan Saint de Venant untuk aliran "Unsteady Flow" pada saluran terbuka adalah sebagai berikut:

\section{Persamaan kekekalan massa:}

$$
\frac{\partial Q}{\partial x}+\frac{\partial A}{\partial t}=0
$$

\section{Persamaan kekekalan momentum:}

$$
\frac{\partial Q}{\partial t}+\frac{\partial}{\partial x}\left(\frac{\beta Q^{2}}{A}\right)+g A\left(\frac{\partial y}{\partial x}\right)+g A \frac{Q^{2}}{K^{2}}=0 \cdots \cdots .2
$$

dimana:

$\mathrm{y}=$ elevasi muka air

$\mathrm{A}=$ penampang melintang aktif dari aliran

$\mathrm{Q}=$ debit aliran

$\mathrm{x}=$ jarak memanjang menurut lembah

$\mathrm{t}=$ waktu

$\beta=$ koefisien momentum untuk distribusi kecepatan

$\mathrm{g}=$ percepatan gravitasi

$\mathrm{K}$ = Conveyance (daya angkut sungai / saluran)

$\mathrm{K}=\frac{\boldsymbol{A}}{n} \boldsymbol{R}^{\frac{2}{3}}$

$\mathrm{n} \quad=$ koefisien kekasaran Manning

$\mathrm{R}=$ jari-jari hidrolis

Terdapat 2 Kondisi Batas dalam metode "Unsteady flow". Kondisi batas atas (upper boundary condition), yang merupakan hydrograph inflow PMF yang menyebabkan keruntuhan bendungan (sejak terjadi rekahan sampai dengan hancur total). Kondisi batas bawah (lower boundary condition), merupakan channel control atau rating curve $\mathrm{H}=\mathrm{f}(\mathrm{Q})$, tinggi gelombang pasang di muara sungai, bangunan struktur lainnya, misalnya tanggul, jalan kereta api, bukit, dan lain-lain tergantung sampai batas mana banjir yang ditimbulkan oleh keruntuhan bendungan terjadi.

\section{HASIL DAN PEMBAHASAN}

\section{a. Sistem Pengaliran}

Bendugan Tugu secara teknis masuk di dalam pengelolaan dan pembinaan Balai Besar Wilayah Sungai Brantas. Bendungan Tugu terletak di Sungai Keser yang merupakan salah satu anak sungai di basin Sungai Ngrowo yang secara administratif masuk dalam Wilayah Desa Nglinggis, Kecamatan Tugu, Kabupaten Trenggalek Propinsi Jawa Timur. Secara geografis terletak pada posisi $111^{0} 34^{\prime}-111^{0}$ 37' Bujur Timur dan $8^{0} 1^{\prime}-8^{0} 3^{\prime}$ Lintang Selatan. 


\section{b. Peta Daerah Tangkapan Air (DTA)}

Luas daerah aliran sungai di lokasi bendungan adalah sebesar $43.06 \mathrm{~km}^{2}$ dengan panjang sungai 9,295 km. Untuk menganalisa hujan rata-rata di daerah aliran sungai Kali Keser di perhitungkan dengan metode Polygon Thiesen dengan menggunakan data hujan dari Stasiun Tugu dan Stasiun Pule. Dapat dilihat pada gambar 3

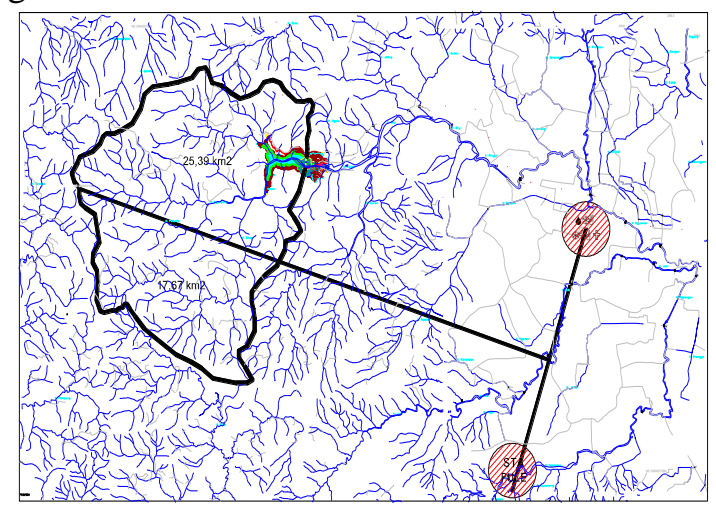

Gambar 3. Peta Daerah Tangkapan Air

Bendungan Tugu

\section{c. Hujan Wilayah}

Untuk analisa hujan daerah di DTA Kali Keser di perhitungkan dengan metode Thiessen dengan menggunakan data hujan dari stasiun terdekat yang berpengaruh terhadap daerah aliran kali Keser, yaitu stasiun Tugu dan stasiun Pule mulai tahun 1995-2014. Metode Poligon Thiesen digunakan karena cara ini memberikan bobot tertentu untuk setiap stasiun hujan dengan pengertian bahwa setiap stasiun hujan dianggap mewakili hujan dalam suatu daerah dengan luas tertentu(Sri Harto $\mathrm{Br}, 1993: 54)$. Hujan maksimum harian tahunan hasil analisa hujan daerah yang digunakan untuk perhitungan hujan rancangan dapat dilihat pada tabel berikut.

Untuk perhitungan koefisien Thiesen DTA Kali Keser dapat dilihat pada tabel 2. Sedangkan Hujan maksimum harian tahunan hasil analisa hujan daerah yang digunakan untuk perhitungan hujan rancangan dapat dilihat pada tabel 3 .

Tabel 2. Koefisien Thiesen DTA Keser

\begin{tabular}{|c|c|c|c|c|}
\hline $\begin{array}{c}\text { Luas DAS } \\
\text { Keser(Km }\end{array}$ & $\begin{array}{c}\text { Stasiun Curah } \\
\text { Hujan (SCH) }\end{array}$ & $\begin{array}{c}\text { Luas Pengaruh Tiap } \\
\text { SCH. }\left(\mathrm{Km}^{2}\right)\end{array}$ & $\begin{array}{c}\text { Prosentase } \\
\text { Terhadap Luas } \\
\text { DAS }\end{array}$ & $\begin{array}{c}\text { Koefisien } \\
\text { Pengaruh (p) }\end{array}$ \\
\hline \multirow{2}{*}{43.06} & Tugu & 25.39 & $58.97 \%$ & 0.59 \\
\cline { 2 - 5 } & Pule & 17.67 & $41.03 \%$ & 0.41 \\
\hline \multicolumn{3}{|c|}{ JUMLAH } & $100.00 \%$ & 1.00 \\
\hline
\end{tabular}

Sumber : Hasil Perhitungan
Tabel 3. Hujan Harian Maksimum Tahunan DTA Keser

\begin{tabular}{|r|r|r|r|r|}
\hline \multirow{2}{*}{ No. } & \multirow{2}{*}{ Tahun } & \multicolumn{1}{c|}{ Tugu } & \multicolumn{1}{c|}{ Pule } & \multicolumn{1}{c|}{ Thiesen } \\
\cline { 3 - 5 } & & $(\mathbf{m m})$ & $\mathbf{( m m )}$ & \multicolumn{1}{c|}{$(\mathbf{m m})$} \\
\hline 1 & 1995 & 92.00 & 90.00 & 91.18 \\
\hline 2 & 1996 & 95.00 & 70.00 & 84.74 \\
\hline 3 & 1997 & 64.00 & 23.00 & 47.18 \\
\hline 4 & 1998 & 68.00 & 85.00 & 74.97 \\
\hline 5 & 1999 & 72.00 & 91.00 & 79.80 \\
\hline 6 & 2000 & 116.00 & 65.00 & 95.08 \\
\hline 7 & 2001 & 79.00 & 60.00 & 71.20 \\
\hline 8 & 2002 & 72.00 & 67.00 & 69.95 \\
\hline 9 & 2003 & 110.00 & 85.00 & 99.74 \\
\hline 10 & 2004 & 98.00 & 87.00 & 93.49 \\
\hline 11 & 2005 & 120.00 & 157.00 & 135.18 \\
\hline 12 & 2006 & 106.00 & 74.00 & 92.87 \\
\hline 13 & 2007 & 160.00 & 234.00 & 190.36 \\
\hline 14 & 2008 & 75.00 & 100.00 & 85.26 \\
\hline 15 & 2009 & 78.00 & 107.00 & 89.90 \\
\hline 16 & 2010 & 73.00 & 120.00 & 92.28 \\
\hline 17 & 2011 & 118.00 & 103.00 & 111.85 \\
\hline 18 & 2012 & 91.00 & 87.00 & 89.36 \\
\hline 19 & 2013 & 107.00 & 85.00 & 97.97 \\
\hline 20 & 2014 & 75.00 & 85.00 & 79.10 \\
\hline
\end{tabular}

Sumber : Hasil Perhitungan

\section{d. Hujan Rancangan}

Hujan rancangan adalah hujan terbesar tahunan dengan peluang tertentu yang mungkin terjadi di suatu daerah, atau hujan dengan suatu kemungkinan periode ulang tertentu. Analisa curah hujan rancangan dilakukan dengan menggunakan metode distribusi E.J. Gumbel, Log Pearson Type III, Log Normal, dan Normal. Hasil perhitungan analisa curah hujan rancangan disajikan pada tabel 4.

Tabel 4. Hasil Perhitungan Analisa Curah Hujan Rancangan

\begin{tabular}{|c|r|r|r|r|}
\hline \multicolumn{1}{|c|}{ T } & Gumbel & Log Pearson III & Log Normal & Normal \\
\hline \hline 2 & 89.16152 & 88.02092654 & 90.1639499 & 93.57309 \\
\hline 5 & 118.0498 & 112.2319498 & 113.296962 & 117.6695 \\
\hline 10 & 137.1763 & 129.2563468 & 127.694588 & 130.2915 \\
\hline 20 & 155.523 & 151.9614193 & 140.825237 & 140.6185 \\
\hline 25 & 161.3428 & 169.7658353 & 145.100546 & 143.774 \\
\hline 50 & 179.2708 & 188.3553859 & 157.431771 & 152.3799 \\
\hline 100 & 197.0665 & 207.8665674 & 169.884658 & 160.412 \\
\hline 1000 & 255.869 & 257.8451167 & 197.286306 & 176.1894 \\
\hline
\end{tabular}

Sumber : Hasil Perhitungan

\section{e. Hujan Rancangan Maksimum Boleh Jadi (PMP)}

Perhitungan hujan maksimum boleh jadi (PMP, Probable maximum Precipitation) dilakukan dengan menggunakan metode Hersfield dengan data hujan 20 tahun (1995- 
2014). Hasil perhitungan hujan PMP dengan metode Hersfield sebesar 582,60 mm.

\section{f. Hujan Efektif}

Hujan efektif adalah bagian hujan total yang menghasilkan limpasan langsung (direct run-off). Dengan asumsi bahwa proses transformasi hujan menjadi limpasan langsung mengikuti proses linier dan tidak berubah oleh waktu (linear and time invariant process). Perhitungan selengkapnya sebaran Hujan Efektif Jam-jaman disajikan pada tabel 5.

Tabel 5. Distribusi Hujan Jam-jaman

\begin{tabular}{|c|c|c|c|}
\hline \multirow{2}{*}{ No } & \multirow{2}{*}{ Jam ke } & $\begin{array}{c}\text { Rasio } \\
(\%)\end{array}$ & Hujan Jam-jaman (mm) \\
\cline { 4 - 4 } & & 31.32 & PMP \\
\hline 1 & 1 & 27.60 & 137.53 \\
\hline 2 & 2 & 20.17 & 121.20 \\
\hline 3 & 3 & 10.18 & 88.60 \\
\hline 4 & 4 & 10.73 & 44.73 \\
\hline 5 & 5 & & 47.11 \\
\hline Probabilitas Hujan Harian & 582.60 \\
Koefisien Pengaliran & & 0.75 \\
Hujan Efektif \\
Sumber: Hasil perhitungan \\
Sul|
\end{tabular}

\section{g. Banjir Rancangan}

Jika tidak tersedia debit pengamatan banjir, maka untuk analisa debit banjir digunakan pendekatan hidrograf satuan, yaitu hidrograf limpasan langsung yang dihasilkan oleh hujan lebih, yang merata di seluruh DPS, dengan intensitas tetap dalam satuan waktu.

Konsep dasar pada hidrograf satuan ialah bahwa hujan satuan yang berbeda-beda besarnya akan menghasilkan grafik distribusi yang hampir sama.

Hidrograf satuan yang digunakan dalam studi ini adalah Hidrograf Satuan Sintetik Nakayasu disajikan pada tabel 6.

Tabel 6. Debit Banjir Rancangan Metode Nakayasu

\begin{tabular}{|c|c|c|c|c|c|c|c|c|}
\hline \multirow{2}{*}{$\begin{array}{c}\text { Waktu } \\
\text { (jam) }\end{array}$} & \multirow{2}{*}{$\begin{array}{c}\mathrm{UH} \\
\left(\mathrm{m}^{3} / \mathrm{d} t / \mathrm{mm}\right)\end{array}$} & \multicolumn{5}{|c|}{ Akibat Hujan } & \multirow{2}{*}{$\begin{array}{c}\text { Base flow } \\
\left(\mathrm{m}^{3} / \mathrm{dt}\right)\end{array}$} & \multirow{2}{*}{$\begin{array}{c}\text { Debit banjir } \\
\left(\mathrm{m}^{3} / \mathrm{dt}\right)\end{array}$} \\
\hline & & 137.53 & 121.20 & 88.60 & 44.73 & 47.11 & & \\
\hline 0.0 & 0.000 & 0.000 & & & & & 0.420 & 0.420 \\
\hline 1.0 & 0.824 & 113.382 & 0.000 & & & & 0.420 & 113.802 \\
\hline 1.8 & 3.379 & 464.711 & 99.919 & 0.000 & & & 0.420 & 565.051 \\
\hline 2.0 & 3.118 & 428.864 & 409.534 & 73.039 & 0.000 & & 0.420 & 911.857 \\
\hline 3.0 & 2.087 & 287.094 & 377.943 & 299.362 & 36.871 & 0.000 & 0.420 & 1001.690 \\
\hline 4.0 & 1.397 & 192.189 & 253.006 & 276.269 & 151.123 & 38.834 & 0.420 & 911.841 \\
\hline 5.0 & 0.961 & 132.147 & 169.369 & 184.943 & 139.465 & 159.168 & 0.420 & 785.512 \\
\hline 6.0 & 0.735 & 101.125 & 116.456 & 123.806 & 93.362 & 146.890 & 0.420 & 582.060 \\
\hline 7.0 & 0.563 & 77.386 & 89.118 & 85.128 & 62.499 & 98.332 & 0.420 & 412.884 \\
\hline 8.0 & 0.431 & 59.220 & 68.198 & 65.144 & 42.974 & 65.826 & 0.420 & 301.781 \\
\hline 9.0 & 0.330 & 45.318 & 52.188 & 49.851 & 32.886 & 45.262 & 0.420 & 225.925 \\
\hline 10.0 & 0.264 & 36.342 & 39.937 & 38.149 & 25.166 & 34.636 & 0.420 & 174.650 \\
\hline 11.0 & 0.216 & 29.735 & 32.027 & 29.193 & 19.258 & 26.505 & 0.420 & 137.138 \\
\hline 12.0 & 0.177 & 24.329 & 26.204 & 23.411 & 14.737 & 20.283 & 0.420 & 109.384 \\
\hline 13.0 & 0.145 & 19.905 & 21.440 & 19.155 & 11.818 & 15.522 & 0.420 & 88.260 \\
\hline 14.0 & 0.118 & 16.286 & 17.542 & 15.672 & 9.670 & 12.448 & 0.420 & 72.037 \\
\hline 15.0 & 0.097 & 13.325 & 14.352 & 12.823 & 7.912 & 10.184 & 0.420 & 59.016 \\
\hline 16.0 & 0.079 & 10.902 & 11.743 & 10.491 & 6.473 & 8.333 & 0.420 & 48.363 \\
\hline 17.0 & 0.065 & 8.920 & 9.608 & 8.584 & 5.296 & 6.818 & 0.420 & 39.646 \\
\hline 18.0 & 0.053 & 7.298 & 7.861 & 7.023 & 4.333 & 5.578 & 0.420 & 32.514 \\
\hline 19.0 & 0.043 & 5.971 & 6.432 & 5.746 & 3.545 & 4.564 & 0.420 & 26.679 \\
\hline 20.0 & 0.036 & 4.886 & 5.262 & 4.702 & 2.901 & 3.734 & 0.420 & 21.905 \\
\hline 21.0 & 0.029 & 3.997 & 4.306 & 3.847 & 2.373 & 3.055 & 0.420 & 17.999 \\
\hline 22.0 & 0.024 & 3.271 & 3.523 & 3.147 & 1.942 & 2.500 & & 14.803 \\
\hline 23.0 & 0.019 & 2.676 & 2.882 & 2.575 & 1.589 & 2.045 & 0.420 & 12.188 \\
\hline 24.0 & 0.016 & 2.189 & 2.358 & 2.107 & 1.300 & 1.673 & 0.420 & 10.048 \\
\hline
\end{tabular}

Sumber : Hasil Perhitungan

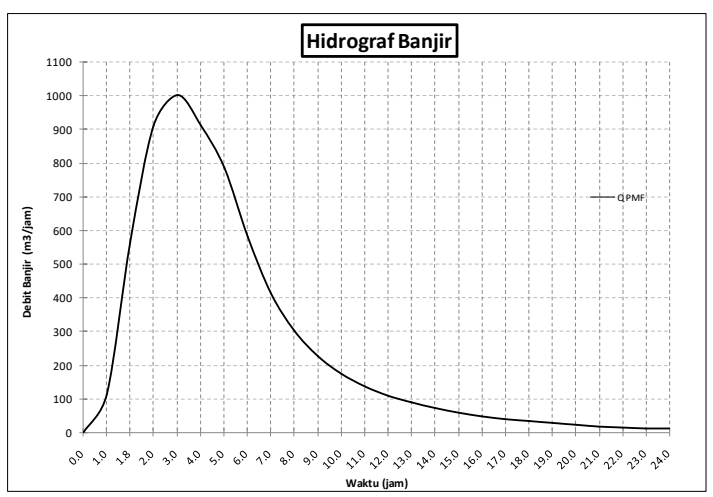

Gambar 4. Grafik Hidrograf Banjir Rancangan $\mathrm{Q}_{\text {pmf }}$ Metode Nakayasu

\section{h. Lengkung Kapasitas Waduk}

Lengkung kapasitas waduk adalah kurva hubungan antara elevasi muka air, volume waduk dan luas genangan waduk pada suatu waktu. Berikut di bawah ini adalah lengkung kapasitas Waduk Tugu

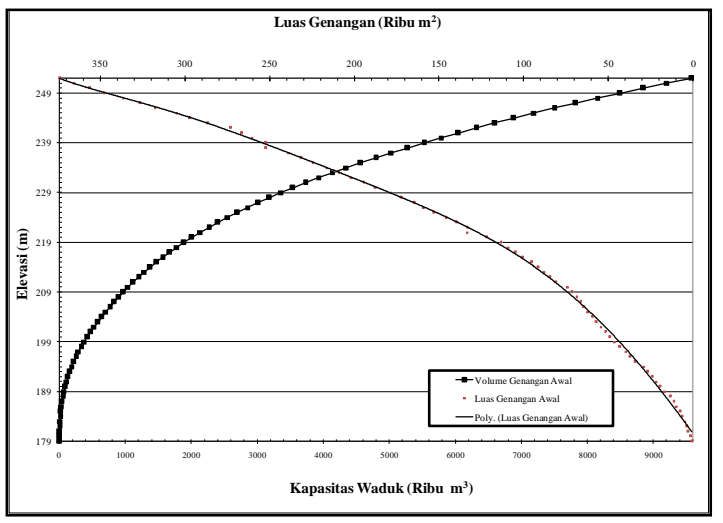

Gambar 5. Lengkung Kapasitas Waduk Bendungan Tugu

\section{i. Skenario Keruntuhan Bendungan}

Dalam studi ini skenario keruntuhan bendungan yang dilakukan adalah simulasi keruntuhan bendungan menggunakan debit banjir PMF dari lateral inflow dari sungai Keser dengan skenario keruntuhan bendungan akibat overtopping dan keruntuhan bendungan akibat piping atas.

Untuk melakukan analisis kerun-tuhan bendungan maka dibutuhkaan input data sebagai berikut:

1) Data teknis bendungan

2) Lengkung kapasitas waduk (H-V-A Curve)

3) Kondisi batas luar (external boundary) yang terdiri dari :

- Kondisi batas atas (upper bounday) yang berupa hidrograf inflow.

- Kondisi batas bawah (lower boundary) dapat berupa data pasang surut muara, 
zero gradient, fixed depth, rating curve, atau control structure, tergantung dimana sungai utama bermuara.

- Batas jaring-jaring elemen beda hingga (finite element mesh boundary)

\section{j. Penetapan Jaring Kerja (Mesh)}

Kerapatan jaring-jaring sangat berpengaruh terhadap tingkat ketelitian hasil penelusuran banjir di hilir. Jaring-jaring kerja dapat dilihat pada gambar 6 .

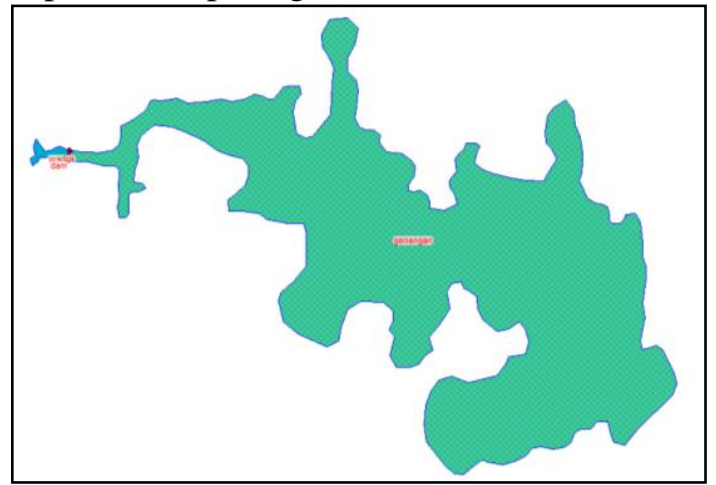

Gambar 6. Jaring-Jaring Kerja (mesh)

\section{k. Analisa Keruntuhan Bendungan}

Dalam analisa keruntuhan Bendungan Tugu dilakukan dengan dua skenario keruntuhan bendungan, yaitu keruntuhan bendungan akibat piping atas (adanya aliran buluh pada elevasi puncak pelimpah) dan keruntuhan bendungan akibat overtopping.

Peta daerah tergenang akibat keruntuhan bendungan didapatkan dengan cara overlay antara peta banjir hasil simulasi dengan peta administrasi daerah. Berdasarkan hasil analisa keruntuhan bendungan akibat piping atas, maka didapatkan lokasi terpilih dapat dilihat pada tabel 6 .

Tabel 6. Lokasi Terpilih Wilayah Rentan Bahaya Keruntuhan Bendungan Tugu

\begin{tabular}{|c|l|c|}
\hline No & Nama Desa & Jarak Dari Bendungan $(\mathrm{m})$ \\
\hline \hline 1 & DESA NGGLIGIS & 500 \\
\hline 2 & DESA PUCANGANAK & 3000 \\
\hline 3 & DESA JAMBU & 5200 \\
\hline 4 & DESA WINONG & 6800 \\
\hline 5 & DESA SUKOREJO & 7500 \\
\hline 6 & DESA GONDANG & 8400 \\
\hline 7 & DESA NGLONGSOR & 9600 \\
\hline 8 & DESA BULUAGUNG & 11500 \\
\hline 9 & KELURAHAN TAMANAN & 13250 \\
\hline 10 & DESA SALAMREJO & 13000 \\
\hline 11 & KELURAHAN KELUTAN & 14850 \\
\hline 12 & KELURAHAN SUMBERGEDONG & 16150 \\
\hline 13 & DESA SAMBIREJO & 16790 \\
\hline 14 & DESA NGADIRENGGO & 18470 \\
\hline
\end{tabular}

1). Skenario keruntuhan bendungan akibat piping atas

Karakteristik banjir di lokasi terpilih yang paling parah adalah Desa Nglinggis pada jarak 500 meter dengan kedalaman banjir 7.26 meter, kecepatan aliran banjir 12.14 meter/detik, dan waktu tiba banjir 41 detik. Dari tabel 7 dapat disimpulkan bahwa 14 desa yang berada di 4 kecamatan, yaitu Kecamatan Tugu, Kecamatan Trenggalek, Kecamatan Karangan, dan Kecamatan Pogalan diperkirakan akan tergenang banjir yang diakibatkan oleh keruntuhan bendu-ngan. Hasil analisa karakteristik banjir akibat keruntuhan bendungan yang terdapat di masing-masing lokasi disajikan pada tabel 7.

Tabel 7. Karakteristik Banjir Keruntuhan Bendungan Akibat Piping Atas

\begin{tabular}{|c|l|r|r|r|r|r|r|}
\hline No & \multicolumn{1}{|c|}{ Nama Desa } & $\begin{array}{c}\text { Jarak Dari } \\
\text { Bendungan } \\
(\mathrm{m})\end{array}$ & $\begin{array}{c}\text { Kedalaman } \\
\text { Banjir Max } \\
(\mathrm{m})\end{array}$ & $\begin{array}{l}\text { Kecepatan } \\
\text { Max }(\mathrm{m} / \mathrm{dt})\end{array}$ & $\begin{array}{c}\text { Waktu } \\
\text { Tiba } \\
(\mathrm{jam})\end{array}$ & $\begin{array}{r}\text { Waktu } \\
\text { Surut } \\
(\mathrm{jam})\end{array}$ & $\begin{array}{r}\text { Durasi } \\
\text { Banjir } \\
(\mathrm{jam})\end{array}$ \\
\hline 1 & DESA NGLINGGIS & 500 & 7.2651 & 12.1411 & 0.01 & 29 & 28.989 \\
\hline 2 & DESA PUCANGANAK & 3000 & 3.032 & 3.0822 & 0.27 & 33 & 32.73 \\
\hline 3 & DESA JAMBU & 5200 & 1.6962 & 2.0908 & 0.69 & 47 & 46.309 \\
\hline 4 & DESA WINONG & 6800 & 1.539 & 1.3205 & 1.43 & 63 & 61.57 \\
\hline 5 & DESA SUKOREJO & 7500 & 1.48 & 1.2725 & 1.64 & 40 & 38.363 \\
\hline 6 & DESA GONDANG & 9400 & 1.3816 & 0.9503 & 2.46 & 29 & 26.545 \\
\hline 7 & DESA NGLONGSOR & 9600 & 1.099 & 1.2206 & 2.18 & 49 & 46.815 \\
\hline 8 & DESA BULUAGUNG & 11500 & 1.1212 & 0.832 & 3.84 & 59 & 55.161 \\
\hline 9 & KELURAHAN TAMANAN & 13250 & 0.6377 & 0.743 & 4.95 & 67 & 62.046 \\
\hline 10 & DESA SALAMREJO & 13000 & 0.698 & 0.2939 & 12.29 & 65 & 52.713 \\
\hline 11 & KELURAHAN KELUTAN & 14850 & 1.2071 & 0.3003 & 13.74 & 62 & 48.264 \\
\hline 12 & KELURAHAN SUMBERGEDONG & 16150 & 0.8325 & 0.2729 & 16.44 & 42 & 25.561 \\
\hline 13 & DESA SAMBIREJO & 16790 & 1.0426 & 0.3141 & 14.85 & 55 & 40.152 \\
\hline 14 & DESA NGADIRENGGO & 18470 & 0.305 & 0.2828 & 18.14 & 66 & 47.858 \\
\hline
\end{tabular}

Sumber : hasil analisa

\section{2) Skenario keruntuhan bendungan Akibat} overtopping

Karakteristik banjir di lokasi terpilih yang paling parah adalah Desa Nglinggis pada jarak 500 meter dengan kedalaman banjir 7.94 meter, kecepatan aliran banjir 12.44 meter/detik, dan waktu tiba banjir kurang dari 40 detik. Hasil analisa karakteristik banjir akibat keruntuhan bendungan yang terdapat di masing - masing lokasi disajikan pada tabel 8 .

Tabel 8. Karakteristik Banjir Keruntuhan Bendungan Akibat Overtopping

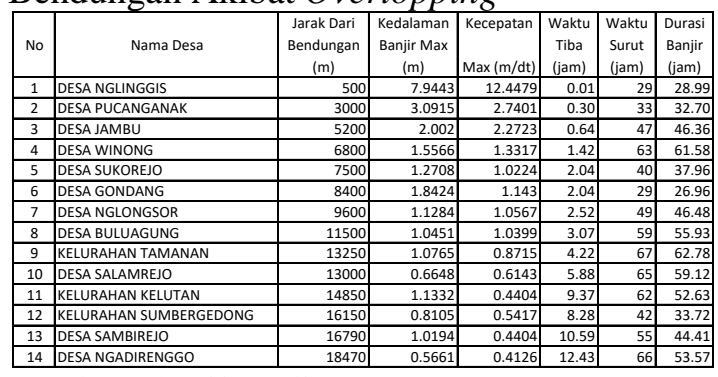

Sumber : hasil analisa 
Dari hasil analisa diatas keruntuhan bendungan dengan skenario overtopping memiliki dampak yang lebih besar daripada keruntuhan bendungan akibat piping atas. Oleh karena itu untuk analisa selanjutnya menggunakan analisa keruntuhan bendungan akibat overtopping.

Karateristik banjir akibat keruntuhan bendungan di setiap lokasi terdampak terdiri dari grafik kedalaman banjir, grafik elevasi banjir dan grafik kecepatan perambatan banjir disajikan pada gambar berikut ini.

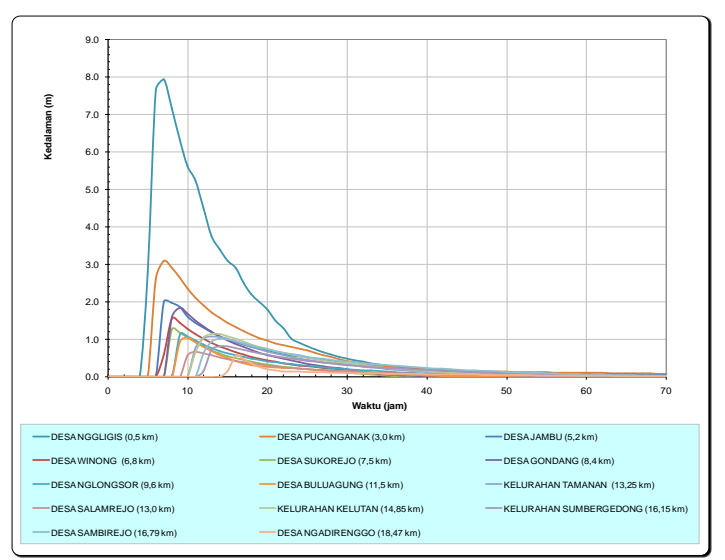

Gambar 7. Grafik Kedalaman Banjir Pada Lokasi Terdampak (Overtopping)

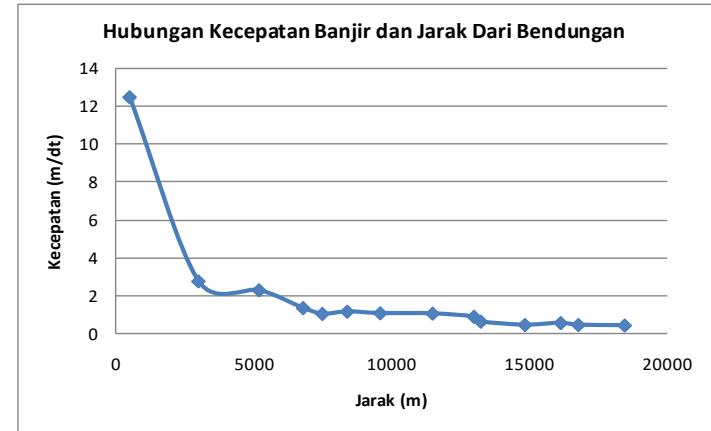

Gambar 8. Grafik Kecepatan Banjir Pada Lokasi Terdampak (Overtopping)

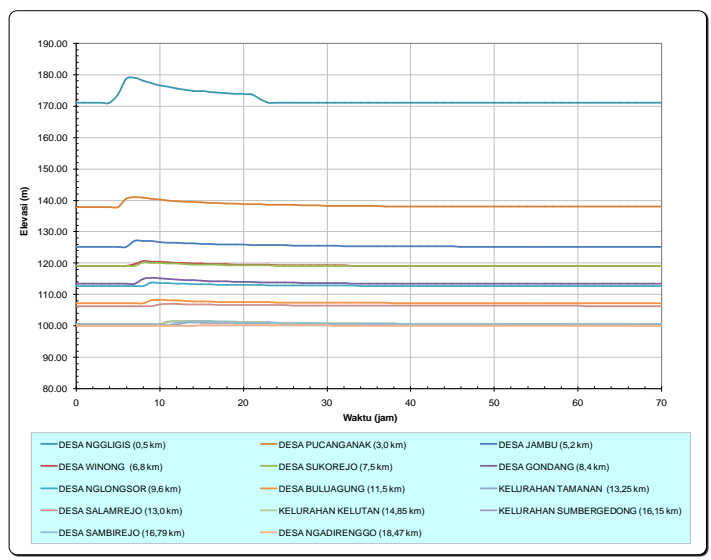

Gambar 9. Grafik Elevasi Muka Air Banjir (Overtopping)
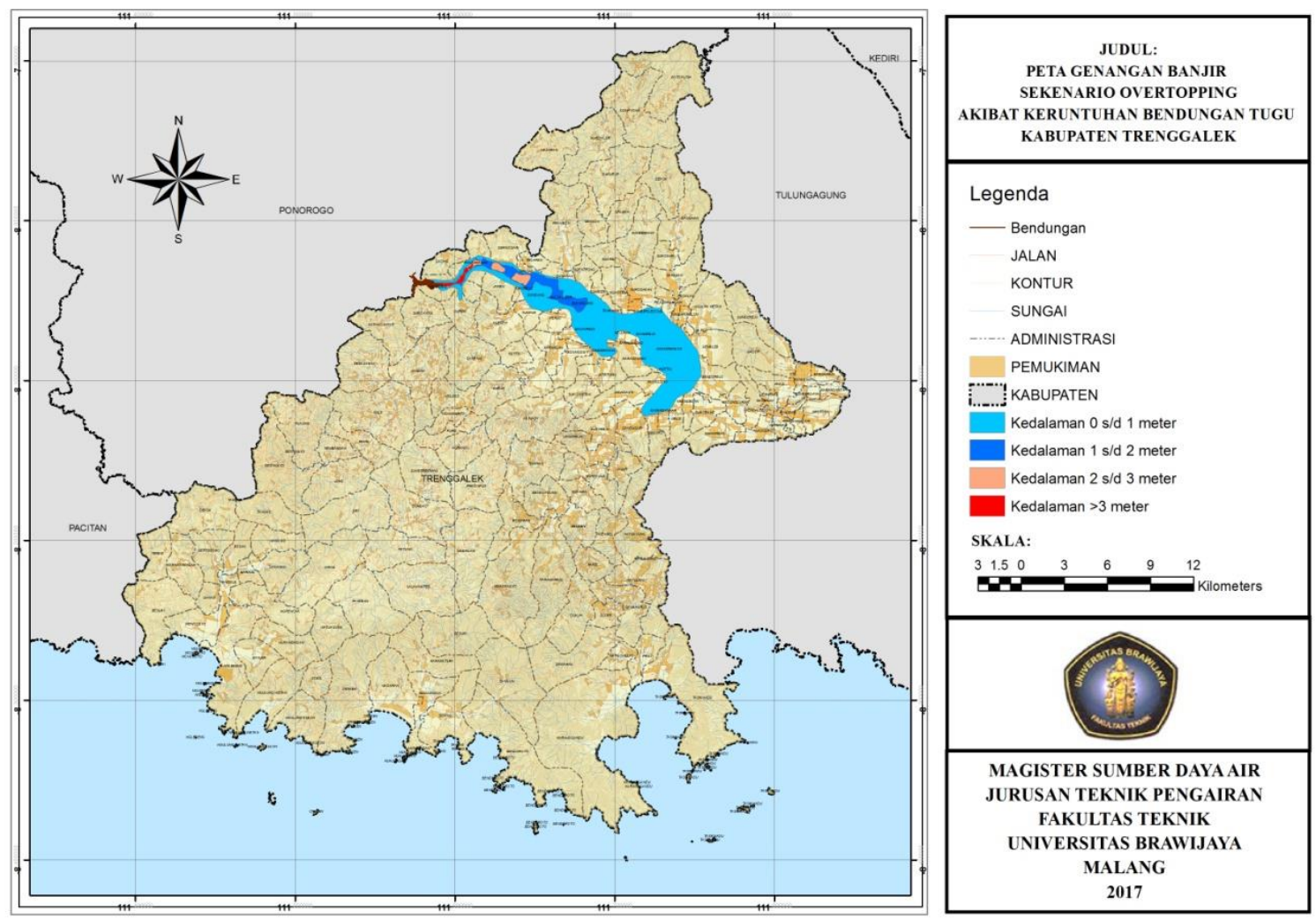

Gambar 10. Peta Resiko Genangan Banjir Akibat Keruntuhan Bendungan 


\section{Penduduk Terkena Resiko}

Analisa sebaran banjir digunakan skenario keruntuhan bendungan akibat overtopping yang secara administratif mencakup 14 Desa, 4 Kecamatan di Wilayah Kabupaten Trenggalek dengan jumlah penduduk yang terkena resiko diperkirakan mencapai 59.925 jiwa.. Berdasarkan SK Dirjen SDA PU, tahun 2011 Bendungan Tugu diklasifikasikan Bahaya Sangat Tinggi. Secara rinci dapat dilihat pada tabel berikut di bawah ini.

Tabel 9. Penduduk Terkena Resiko

\begin{tabular}{|c|c|c|c|c|c|}
\hline \multirow[b]{2}{*}{ No } & \multicolumn{2}{|l|}{ Lokasi Terdampak } & \multicolumn{2}{|c|}{ Jumlah Perris } & \multirow[b]{2}{*}{$\begin{array}{l}\text { Klasifikasi } \\
\text { Hazard }\end{array}$} \\
\hline & Nama Desa & $\begin{array}{c}\text { Jarak Dari } \\
\text { Bendungan } \\
\text { (m) }\end{array}$ & Jiwa & KK & \\
\hline 1 & DESA NGLINGGIS & 500 & 2539 & 615 & 4 \\
\hline 2 & DESA PUCANGANAK & 3000 & 3801 & 921 & 4 \\
\hline 3 & DESA JAMBU & 5200 & 4585 & 1112 & 4 \\
\hline 4 & DESA WINONG & 6800 & 2625 & 636 & 4 \\
\hline 5 & DESA SUKOREOO & 7500 & 1970 & 47 & 4 \\
\hline 6 & \begin{tabular}{|l|} 
DESA GONDANG \\
\end{tabular} & 8400 & 6445 & 1562 & 4 \\
\hline 7 & DEAA NGLONGSOR & 9600 & 5121 & 1241 & 4 \\
\hline 8 & DESA BUIUAGUNG & 11500 & 2773 & 672 & 4 \\
\hline 9 & KELURAHAN TAMANAN & 13250 & 6358 & 1541 & 4 \\
\hline 10 & DESA SALAMREO & 13000 & 4224 & 1023 & 4 \\
\hline 11 & KELURAHAN KEUTAN & 14850 & 3701 & 897 & 4 \\
\hline 12 & KELURAHAN SUMBERGEDONG & 16150 & 5283 & 1280 & 4 \\
\hline 13 & DEA SAMBIREIO & 16790 & 2713 & 657 & 4 \\
\hline 14 & DESA NGADIRENGGO & 18470 & $6 / 87$ & 1645 & 4 \\
\hline
\end{tabular}

Sumber: hasil analisa

Dari hasil analisa klasifikasi zona bahaya dapat disimpulkan ada 3 (tiga) desa berada pada zona bahaya tinggi, ada 8 (delapan) desa berada pada zona bahaya sedang, dan ada 3 (tiga) desa berada pada zona bahaya rendah. Desa Nglinggis, Desa Pucanganak, dan Desa Jambu diprioritaskan untuk segera mengungsi pada saat Kondisi Siaga. Sedangkan penduduk di desa lainnya dapat mengungsi pada Kondisi Awas dapat dilihat pada tabel 10 .

Tabel 10. Klasifikasi Zona Bahaya

\begin{tabular}{|c|c|c|c|c|c|}
\hline \multirow[b]{2}{*}{ No } & \multicolumn{2}{|l|}{ Lokasi Terdampak } & \multirow[b]{2}{*}{$\begin{array}{c}\text { Kedalaman } \\
\text { Banij } \\
\text { (m) }\end{array}$} & \multirow[b]{2}{*}{$\begin{array}{c}\text { Kecepatan } \\
\text { Banjir } \\
\text { (m/d) }\end{array}$} & \multirow[b]{2}{*}{$\begin{array}{l}\text { Zona } \\
\text { Bahaya }\end{array}$} \\
\hline & Nama Desa & $\begin{array}{c}\text { barat Dari } \\
\text { Bendungan } \\
\text { (m) }\end{array}$ & & & \\
\hline $\mathbf{1}$ & DESA NGLINGGIS & 500 & 7.9443 & 124479 & 3 \\
\hline 2 & DESA PUCANGANAK & 3000 & 3.0915 & 27401 & 3 \\
\hline 3 & DESA LAMBU & 5200 & 2000 & 22723 & 3 \\
\hline 4 & DESA WINONG & 6800 & 1.5566 & 13317 & 2 \\
\hline 5 & DESA SUKOREIO & 7500 & 12708 & 100224 & 2 \\
\hline 6 & DESA GONDANG & 8400 & 18424 & 1.143 & 2 \\
\hline 7 & DESA NGLONGSOR & 9600 & 1.1284 & 1050 & 2 \\
\hline 8 & DESA BULUAGUNG & 11500 & 10451 & 10899 & 2 \\
\hline 9 & KELURAHAN TAMANAN & 13250 & 1076 & 08715 & 2 \\
\hline 10 & DESA SALAMRE 0 & 13000 & a.6648 & 06143 & $\mathbf{1}$ \\
\hline 11 & KELURAHAN KELUTAN & 1480 & 1.1332 & $\mathbf{0 4 4 0 4}$ & 2 \\
\hline 12 & KELURAHAN SUMBERGEDONG & 16150 & a8105 & $\mathbf{0 . 5 4 1 7}$ & 1 \\
\hline 13 & DESA SAMBIREO & 16790 & 10194 & $\mathbf{0 4 4 0 4}$ & 2 \\
\hline 14 & DESA NGADIREMGGO & 184\%0 & a5661 & $\mathbf{0 . 4 1 2 6}$ & 1 \\
\hline
\end{tabular}

Sumber: hasil analisa

\section{KESIMPULAN}

Dari hasil analisis terhadap simulasi keruntuhan Bendungan Tugu dapat disimpulkan hal - hal berikut di bawah ini:
1. Simulasi keruntuhan dapat dilakukan dengan menggunakan perangkat lunak HEC-RAS 5.0.1. Sebaran banjir yang terjadi akibat keruntuhan Bendungan Tugu dengan skenario overtopping memiliki dampak yang lebih besar daripada skenario akibat piping atas. Pada skenario keruntuhan akibat overtopping karak-teristik banjir di lokasi terpilih yang paling parah adalah Desa Nglinggis pada jarak 500 meter dengan kedalaman banjir 7.94 meter, kecepatan aliran banjir 12.44 meter/detik, dan waktu tiba banjir kurang dari 40 detik.

2. Karakteristik banjir yang terjadi di setiap lokasi terdampak mempunyai waktu kedatangan tercepat 0.01 jam atau krang dari 40 detik untuk Desa Nglinggis yang berada 500 meter dari Bendungan Tugu, serta waktu paling lambat terjadi pada 12,43 jam yang terjadi pada lokasi yang berjarak $18.4 \mathrm{~km}$ dari bendungan. Sedangkan durasi banjir tercepat adalah 26,96 jam dan terlama adalah 62,78 jam.

3. Dari hasil analisa klasifikasi zona bahaya dapat disimpulkan ada 3 (tiga) desa berada pada zona bahaya tinggi, ada 8 (delapan) desa berada pada zona bahaya sedang, dan ada 3 (tiga) desa berada pada zona bahaya rendah. Desa Nglinggis, Desa Pucanganak, dan Desa Jambu diprioritaskan untuk segera mengungsi pada saat Kondisi Siaga. Sedangkan penduduk di desa lainnya dapat mengungsi pada Kondisi Awas.

4. Rekomendasi pencegahan keruntuhan Bendungan Tugu

a. Rekomendasi pencegahan kerun-tuhan bendungan akibat overtopping dapat dilakukan dengan cara teknis maupun non teknis. Rekomendasi teknis untuk mencegah keruntuhan bendungan tugu berda-sarkan dari hasil analisa yaitu, Membutuhkan lebar pelimpah yang semula 22 meter menjadi 28 meter dengan membuat emergency spillway dengan lebar minimal 6 meter, rekomendasi ini dengan memperhitungkan tinggi jagaan sebesar 1 meter. Atau meninggikan tubuh bendungan sebesar 1 meter, dari elevasi +259 menjadi elevasi +260 . Sedangkan rekomendasi dengan cara non teknis yaitu dengan aspek pengelolaan DAS di hulu bendungan. Aspek pengelolaan DAS antara lain meliputi, mengurangi erosi pada DAS, mengembalikan dan 
meningkatkan produktivitas lahan, menekan laju pertambahan lahan kritis, mening-katkan daya serap DAS, mengurangi debit banjir, memperpanjang proses pendangkalan waduk.

b. Rekomendasi Pencegahan Keruntuhan Bendungan Akibat Piping. Keruntuhan bendungan akibat piping dapat dicegah dengan cara melakukan ispeksi dan pemantauan secara berkala. Inspeksi dan pemantauan secara berkala sangat diperlukan karena dapat mengetahui secara dini kerusakan bendungan akibat piping. Rekomendasi pencegahan keruntuhan bendungan akibat piping adalah:

- Memonitor secara intensif pada instrumen bendungan.

- Melakukan analisa kerusakan pada tubuh bendungan .

- Melakukan perbaikan pada kerusakan bendungan dengan segera.

- Menurunkan elevasi muka air bendungan dibawah elevasi kerusakan pada tubuh bendungan.

\section{SARAN}

Berdasarkan kesimpulan yang telah dikemukakan tersebut diatas, berikut ini disampaikan beberapa saran yang terkait dengan studi ini antara lain :

1. Perlu dibangun sistem peramalan banjir dan peringatan dini (Flood Warning and Forcasting System) untuk Bendungan Tugu berupa pemasangan perangkat telemetry warning system.

2. Flood Warning and Forecasting System yang disarankan adalah suatu sistem yang dapat digunakan untuk meramal tentang waktu dan besarnya muka air dan debit yang akan terjadi pada suatu titik pengamatan yang terjangkau di dalam sistem tersebut sehingga dapat memberikan informasi secara dini kepada masyarakat di daerah rawan banjir. Pada dasarnya sistem ini terdiri dari 2 (dua) komponen utama yaitu komponen hardware (perangkat keras) dan komponen software (perangkat lunak).

\section{DAFTAR PUSTAKA}

Abdurrachman, Mochammad Imam, 2016. Studi Analisa Penelusuran Banjir Akibat keruntuhan Bendungan Jatigede Kabupaten Sumedang Jawa Barat

http://pengairan.ub.ac.id/wpcontent/uploads/01 6/01/Studi-Analisa-PenelusuranBanjirAkibat - Keruntuhan - Bendungan-Jatigede - Kabupaten - Sumedang-JawaBarat-Muhammad-ImamAbdurrahman -0910643023.pdf

Aniskurlillah, Sona Gusti, 2014. Aplikasi Zhong Xing Hy21 Untuk Analisa Keruntuhan Bendungan Muka Kuning Batam.

http://pengairan.ub.ac.id/wp-content/uploads/ 2014/02/Aplikasi-Zhong-Xing-HY21 Untuk-Analisa-Keruntuhan-Bendungan - Muka - Kuning -Batam-Sona Gusti-Aniskurlillah.pdf

Aryadi, Eric Virgiawan, 2014. Analisa Keruntuhan Bendungan Gondang Dengan Menggunakan Program Zhong Xing Hy21.

http://jurnalpengairan.ub.ac.id/index.php/jtp/art icle/download/210/204

Asdak, C. 1995. Hidrologi dan Pengelolaan Daerah Aliran Sungai. Gadjah Mada University Press. Yogyakarta

Chow, Ven Te. 1985. Hidrolika Saluran Terbuka (Open Chanel Hydraulics). Terjemahan Suyatman, VFX Kristanto Sugiharto dan E.V. Nensi Rosalina. Jakarta : Erlangga

Limantara, L. M. 2010. Hidrologi Praktis. Penerbit Lubuk Agung. Bandung.

Masrevaniah, Aniek , 2010. Konstruksi Bendungan 1. Malang : Penerbit IKIP Malang

Permana, Mikail Adhi, 2015. Analisa Keruntuhan Bendungan Mamak Dan Bendungan Batu Bulan Secara Simultan Pada System Pengaliran Sungai Dendritik. Tidak diterbitkan

Soemarto, C. D. 1987. Hidrologi Teknik. Penerbit Usaha Nasional. Surabaya. 